This is an electronic reprint of the original article. This reprint may differ from the original in pagination and typographic detail.

Author(s): Hänninen, Nora; Karjaluoto, Heikki

Title: $\quad$ The effect of marketing communication on business relationship loyalty

Year: $\quad 2017$

Version:

Please cite the original version:

Hänninen, N., \& Karjaluoto, H. (2017). The effect of marketing communication on business relationship loyalty. Marketing Intelligence and Planning, 35(4), 458-472. https://doi.org/10.1108/MIP-01-2016-0006

All material supplied via JYX is protected by copyright and other intellectual property rights, and duplication or sale of all or part of any of the repository collections is not permitted, except that material may be duplicated by you for your research use or educational purposes in electronic or print form. You must obtain permission for any other use. Electronic or print copies may not be offered, whether for sale or otherwise to anyone who is not an authorised user. 


\section{eemeraldinsight}

\section{Marketing Intelligence \& Planning}

The effect of marketing communication on business relationship loyalty

Nora Hänninen, Heikki Karjaluoto,

\section{Article information:}

To cite this document:

Nora Hänninen, Heikki Karjaluoto, (2017) "The effect of marketing communication on business relationship loyalty",

Marketing Intelligence \& Planning, Vol. 35 Issue: 4,pp. -, doi: 10.1108/MIP-01-2016-0006

Permanent link to this document:

http://dx.doi.org/10.1108/MIP-01-2016-0006

Downloaded on: 05 April 2017, At: 23:55 (PT)

References: this document contains references to 0 other documents.

To copy this document: permissions@emeraldinsight.com

The fulltext of this document has been downloaded 3 times since 2017*

Access to this document was granted through an Emerald subscription provided by emerald-srm: 306933 []

\section{For Authors}

If you would like to write for this, or any other Emerald publication, then please use our Emerald for Authors service information about how to choose which publication to write for and submission guidelines are available for all. Please visit www. emeraldinsight. com/ authors for more information.

\section{About Emerald www.emeraldinsight.com}

Emerald is a global publisher linking research and practice to the benefit of society. The company manages a portfolio of more than 290 journals and over 2,350 books and book series volumes, as well as providing an extensive range of online products and additional customer resources and services.

Emerald is both COUNTER 4 and TRANSFER compliant. The organization is a partner of the Committee on Publication Ethics (COPE) and also works with Portico and the LOCKSS initiative for digital archive preservation.

*Related content and download information correct at time of download. 


\title{
The effect of marketing communication on business relationship loyalty
}

\begin{abstract}
Purpose - The purpose of this study is to create a new understanding of industrial business-tobusiness (B2B) relationships by connecting the theoretical streams of marketing communications and relationship marketing. This study tests how various marketing communication channels and communication quality increase the transformation of customer-perceived value into customer loyalty.
\end{abstract}

Design/methodology/approach - The theoretical framework consists of links between customerperceived value, marketing communication quality, channel effectiveness and customer loyalty. The age of the business relationship is also taken into consideration. Empirical testing is based on global survey data $(\mathrm{N}=121)$ collected from customers of Finnish manufacturing companies operating in the paper, mineral and metal-processing industries.

Findings - The effects of customer-perceived value on customer loyalty are both direct and indirect, as marketing communications partially mediate this relationship. The customer-perceived effectiveness of various marketing communication channels adds more to loyalty formation than the perceived quality of marketing communications.

Practical implications - Of special interest for marketing practitioners is the channel-specific approach to the effectiveness of marketing communications. Results suggest that personalized channels would be the most important mediators of the effects of perceived value on loyalty but 
also bring up the possibility of combining personalized direct communication with new costeffective digital channels.

Originality/value - Relatively little research has examined the mediating role of marketing communications in the relationship between perceived value and loyalty in the business-to-business context.

Keywords B2B relationships, Industrial marketing, Communication channels, Perceived value, Loyalty

Paper type Research paper 


\section{The effect of marketing communication on business relationship loyalty}

\section{Introduction}

Communication is a key element of all business relationships. Across studies and contexts, interfirm communication is found to have mainly positive effects on the relationship, as communication mediates various important relationship outcomes (Duncan and Moriarty, 1998). Communication affects satisfaction (Cannon and Perreault, 1999; Mohr and Sohi, 1995), trust (Morgan and Hunt, 1994) and loyalty (Scheer et al., 2009) Communication also serves as a means of relational governance that increases affective commitment toward the business relationship (Mohr et al., 1996). It is generally thought that suppliers' investments in long-term relationships pay off in the form of increased value for the customer, which, in turn, strengthens customers' intentions to make future purchases from the same supplier (Hutchinson et al., 2011). As for the objectives of customer retention (loyalty and future purchase intentions), it is crucial for the supplier to know the customer's experience with perceived value as the ultimate relationship outcome (Sirdeshmukh et al., 2002). Future purchases are only attained if the customer is convinced about the supplier's offering as the most valuable in the market. Despite the existing body of knowledge on interfirm communication, less is known about the role of marketing communications in business relationships (Andersen, 2001), although communication is an essential element of a value-based approach to relationships (Sharma et al., 2001). Marketing communications is suggested to have a mediating role in the transformation of perceived value into loyalty in its various forms, from attitudinal to behavioral elements (Gilliland and Johnston, 1997; Keller, 2009).

Andersen (2001) notes that marketing communications in the B2B context may have been considered irrelevant due to the claimed unidimensionality in comparison to the interactional mutuality of the B2B relationship. Traditionally, marketing communication has been likened to advertising and the one-way communications that take place in mass channels and aim to persuade 
new prospects to consider transactions (Duncan and Moriarty, 1998) whereas business-to-business (B2B) relationships have been seen as highly relationship-oriented and personal (Coviello and Brodie, 2001). However, transactional and relational marketing objectives should not be seen as exclusive, as both are required during the course of a successful business relationship (Peltier et al., 2006). Transactions should be understood as the critical turning points of a relationship where relational attitudes and value assessment manifest in the customer's behavior. Therefore, understanding the role of marketing communications as supplier-initiated communication that has the aim of persuasion (Andersen, 2001) is critical, considering its role in fostering customer loyalty. This study contributes to the knowledge on industrial relationships and customer behavior by combining the relationship-oriented, value-based approach with the added aspect of marketing communications. The objective of this study is to examine how customer-perceived value is linked to customer loyalty through communication channel effectiveness and communication quality.

From the marketing practitioner's perspective, the challenge in successful marketing communication lies in the optimal allocation of resources (Anderson et al., 1987). Researchers have explored the channel mix of marketing communication in the B2B context (McArthur and Griffin, 1997; Sharma and Mehrotra, 2007), but less is known about the customer's preferences for receiving communication from the supplier, especially regarding the relatively novel digital channels (Järvinen et al., 2012). Due to the differences in communication channels or tools in terms of effectiveness and cost, this study examines marketing communications as divided into mass media, personal and device-mediated channels. This channel-wise approach has not been widely employed although it benefits marketing managers who are attempting to maximize the effectiveness of the communications mix. As a result, the cultivation of long-term B2B relationships can be considered without neglecting the reality of intense competition in global industrial markets. 
This research article proceeds as follows. In the next section, relevant literature is reviewed to understand what is already known about the relationships between value, loyalty and marketing communications. Then, the research model with hypotheses is presented. Subsequently, the study's methodology and empirical context are discussed, followed by empirical analysis. Finally, the results and their contribution to the theoretical and practical understanding of industrial marketing are discussed, and limitations and further research topics are addressed.

\section{Literature review}

\subsection{Perceived value and loyalty as the key relationship outcomes}

The concept of perceived value originated in consumer research and was formulated to represent the "tradeoff between sacrifice and benefit" that the customers assesses when choosing between competing offerings and making a purchasing decision (Zeithaml, 1988). Since then, perceived value has been considered the "ultimate customer outcome" (Sirdeshmukh et al., 2002). Zeithaml's (1988) definition of perceived value implied two essential aspects that have guided theoretical and empirical research on the topic. First, perceived value is the customer's assessment of the cost and the benefit gained from a purchase. Second, perceived value is assessed in comparison to competing offers. When these two aspects are combined, customer behavior in a competitive market can be understood (Zeithaml, 1988). Among industrial customers, technical quality and functional value are often found to be the most important drivers of value (Bell et al., 2005; Ulaga and Chacour, 2001). This study follows a commonly employed conceptualization of customer-perceived value in $\mathrm{B} 2 \mathrm{~B}$ markets as comprising of price- and quality-related drivers.

Whereas customers seek superior value from business relationships, suppliers hope to gain loyal customers because long-term relationships are generally considered profitable for the supplier. Loyalty is a multifaceted concept that consists of attitudinal and behavioral elements and manifests 
as the customer's intention to continue the relationship, repurchasing actions and positive referrals (Bell et al., 2005; Scheer et al., 2009). An especially interesting aspect of loyalty is word-of-mouth (WoM) or recommendations that is considered as a key indicator of genuine loyalty in relationship marketing literature (Andreassen and Lindestad, 1998; Lam et al., 2004). Recommendation reveals the customer's positive attitude in a behavioral form (Lam et al., 2004) and is not dependent of the relationship phase and investment cycle (Andreassen and Lindestad, 1998). Therefore, a loyal customer may contribute to the supplier's benefiting from the business relationship even if, for example, repurchases are not on the customer's current agenda. In Kuhn et al.'s (2008) sample of B2B customers, although the respondents had no first-hand experience with a supplier's brand, they had formulated a perception about at least the adequate performance of the supplier based on the experiences of others in the same field of business. This result suggests that WoM as a key indicator of loyalty is very important in B2B marketing. Increased customer loyalty not only affects the direct relationship outcomes but also is an investment in creating brand awareness and value perceptions among prospects.

\subsection{Marketing communication in B2B relationships}

Traditionally, the linkage of value and loyalty has been considered direct (Harris and Goode, 2004) but support for mediation effects between the link of value and loyalty are also found in the empirical literature. Evidence from previous research suggests that marketing communication as a means of shaping customer perceptions affects the link between value perceptions and behavioral intentions in the future. Marketing communication that meets receiver-specific needs increases value and loyalty in business relationships (Peltier et al., 2006). Engaging the customer in interactions with the supplier may increase active customer loyalty (Sashi, 2012), and positive associations about a brand may be strengthened by communication (Keller, 2009). Evidence from the consumer context suggests that marketing communication has a mediating role in the attitude- 
behaviour linkage (Kwak et al., 2006). Customer-perceived value has been shown to affect the customer's assessment of the supplier's marketing communication, which, in turn, aims at enhancing other relationship outcomes, especially future purchasing intentions (Keller, 2009).

Some empirical evidence from the B2B context confirms the cumulative benefits of marketing communications as building favorable customer attitudes that elicit further information seeking and, in turn, influence purchasing behavior (Gilliland and Johnston, 1997). Gilliland and Johnston (1997) introduce a marketing communications effectiveness model and propose that customer attitudes towards and evaluations about a brand affect the way they tune in to further marketing communications by the same brand. Key point regarding the interplay of perceived value and marketing communications is that those buyers who evaluate the supplier more positively also seek more information and engage in greater influence attempts, making the supplier's communication efforts more effective (Gilliland and Johnston, 1997).

\subsubsection{Channel effectiveness}

Channel effectiveness may be defined as the perceived match of the channel used and customer preferences regarding the modes of interaction (Mohr et al., 1996). Although the most commonly used tools in B2B marketing communications are still personal selling (the most important), customer relationship marketing, trade shows and PR (De Pelsmacker et al., 2007), changing communication habits have drastically affected the way people communicate with each other and how people acquire, gather and share information about products and offerings (Hennig-Thurau et al., 2010). Empirical studies show the importance of other sources of information for industrial buyers: third-party information, e-mail, websites, telephone calls, trade shows (Adamson et al., 2012) and social media (Järvinen et al., 2012). 
Social media tools, such as blogs, wikis, discussion forums and social networking sites, have recently been of interest in industrial marketing communications (Järvinen et al., 2012; Taiminen and Karjaluoto, 2015). At the same time, the potential of social media remains largely unused among business marketers (Jussila et al., 2014). The gap between the perceived benefits and actual implementation of social media may result from the fact that the digital tools such as industrial websites and e-mail are not a replacement for offline tools but instead are an additional resource for attaining marketing and communication objectives (Cawsey and Rowley, 2016; Karjaluoto et al., 2015). In other words, the mere usage of social media does not transfer directly to relationship outcomes but only after developing customer-centric communication capabilities with the help of social media, customer satisfaction and loyalty may be increased (Trainor et al., 2014).

\subsubsection{Communication quality}

Marketing communications is essentially a supplier-initiated form of communication but, in order to yield positive effects, it should be in line with customer expectations regarding the interaction that takes place in the relationship. In this study, the supplier's success in meeting customer expectations is conceptualized as communication quality. The drivers of communication quality vary across studies. Good-quality communication is relevant, timely and reliable (Mohr and Spekman, 1994; Morgan and Hunt, 1994). Communication quality is a combination of information quality and source preference (Harcourt et al., 1991) or the delivery of adequate, timely, accurate, complete and credible communication (Mohr and Sohi, 1995). Ball et al. (2004, p. 1277) define good communication as providing "information in such a way that the customer personally benefits with a minimum of effort necessary to decode the communication and determine its utility". The buyer's willingness to engage in a mutual relationship with the supplier affects the buyer's preferences regarding interaction with a supplier (Palmatier et al., 2008), indicating that the criteria of good communication may vary between customers. 
Currently, there is much discussion about "information overload" and its effects on customers' willingness and ability to process marketing communication. Recently, information overload has been examined in the context of social media (Bawden and Robinson, 2009; Sasaki et al., 2015). Bright et al. (2015) discuss audiences' avoidance of social media participation due to information overload. However, the industrial marketing context is fundamentally different from the consumer context. Someone who is interested in a particular topic (such as a professional buyer) is actually more willing and able to process more information when it is relevant (Gilliland and Johnston, 1997). Larger volume and higher frequency are considered favorable in collaborative relationships (Mohr and Sohi, 1995). Based on the existing literature, good-quality communication is characterized as sufficiently frequent, useful in terms of content, sent through suitable channels and perceived as efficient.

\subsection{The effect of customer-perceived value and marketing communication on customer loyalty}

Literature suggests that customer-perceived value increases customer loyalty (Harris and Goode, 2004; Sirdeshmukh et al., 2002) but higher value assessment also enhances the customer's receptiveness to supplier's marketing communications (Gilliland and Johnston, 1997). When the supplier's marketing communication is perceived as effective and of good quality, it, in turn, increases the customer's loyalty towards the supplier (Ball et al., 2004). Perceived effectiveness and quality of marketing communication mediate the customer's experience about the supplier, having potential effect on future intentions (Dwyer et al., 1987; Palmatier et al., 2008). Therefore, marketing communication has a critical role as a mediator between a customer's past and current experience and future behavior. Based on these findings, it is assumed that industrial buyers with a positive evaluation of their supplier also process the supplier's communication more favourably and 
feel more loyal to their suppliers (Gilliland and Johnston, 1997), leading to a mediation effect of marketing communication in the value-loyalty link. Against this backdrop, the first hypothesis is set:

H1: The effects of customer-perceived value on loyalty are both direct and indirect as they are mediated by channel effectiveness and communication quality

As for the effectiveness of different communication channels, face-to-face interaction is equally considered as the most effective and preferred mode in $\mathrm{B} 2 \mathrm{C}$ and $\mathrm{B} 2 \mathrm{~B}$ contexts alike (Ball et al., 2004; Coviello and Brodie, 2001). Personalized communication requires least decoding effort from the receiver (Ball et al., 2004) thus manifesting the supplier's willingness to put effort into the relationship and therefore more worthwhile. Based on previous knowledge, it is assumed that personalized, face-to-face modes of communication are preferred by the customer and are considered more effective, leading to the second hypothesis:

$\mathrm{H} 2$ : The indirect effect of perceived value and the mediating effect of communication are stronger for personalized and more effective communication channels than for non-personalized and less effective communication channels.

In the model, the length of the relationship was controlled. The relationship marketing approach emphasizes the benefits of long-lasting relationships as favorable outcomes are increased in longerterm relationships (Coulter and Coulter, 2002).

\section{Methodology}

\subsection{Measures}


Measures for the survey instrument were adapted from previous literature either as used in previous studies or modified to match the context of this study. The scale for perceived value was adapted from prior studies and consisted of items regarding product performance, quality, cost and image on a seven-point Likert scale (Ciavolino and Dahlgaard, 2007; Fang et al., 2008; Sweeney and Soutar, 2001; Ulaga and Eggert, 2006). The effectiveness of different communication channels was measured on a semantic differential scale employing a ten-item list of communication modes adapted from Mohr et al. (1996). Based on an exploratory factor analysis, three sub-categories of the items were formed. The first category consisted of personal and direct communication, such as face-to-face interaction. The second category represented traditional mass channels, such as advertising and magazines. The third category included telephone and e-mail, which may be characterized as direct device-related communication channels. In the following analyses, these communication channels are named "face-to-face," "mass channels" and "personal via device." Communication quality was measured on a seven-point Likert scale that was adapted from previous literature on the quality of communication in general, emphasizing the frequency, content, suitability of channels and efficiency (del Bosque Rodríguez et al., 2006; Harcourt et al., 1991). The three-item, 10-point scale for loyalty was adapted from Sirdeshmukh et al. (2002). Relationship age was surveyed with an open question regarding the length of the particular supplier relationship in years $(M=17.6$ years, $S D=12.05)$. In the analyses, relationship age was recoded into four categories ranging from $1=$ less than five years to $4=20$ years or more. A list of the items is shown in Table I.

"Table I about here"

\subsection{Sampling}


The empirical data were collected from companies operating in the pulp and paper, mineral and mining industries. These industries are mature, resource-intensive industries in which competition is high and the supplier's products are critical to the success of the customer's operations. Investment cycles of such complex industrial products may be of decades long. These businesses may be a specific case of relationship cultivation compared to other kinds of supply chains or partnerships in which exchange takes place during shorter time spans. The supplier companies were three Finnish firms: Two are listed on public stock exchanges and operate worldwide, and the third operates mainly in domestic markets.

Data were collected using an online survey with the help of supplier company representatives (marketing managers) who had access to their company's global customer databases with detailed contact information. The supplier company representatives compiled the lists of respondents and sent the cover letter by e-mail. The target respondents were managers who were responsible for purchasing decisions in their organizations. The cover letter e-mail encouraged the respondents to visit an online survey site, independent of the supplier company. Naturally, the confidentiality of the responses was emphasized in the cover letter e-mail preceding the link to the online survey. Only the research team had access to the data, which was also explained in the cover letter. The response rate was increased by announcing a lottery in which the respondents could participate without risking their anonymity. Non-response bias was assessed by comparing early and late respondents (Armstrong and Overton, 1977), but no statistically significant differences were found $(p<.05)$ in the data.

To ensure the equivalence in the data collection in terms of the survey instrument translation from Finnish into English, German and Chinese, and in the international sample collected, the following 
steps were taken (Coviello and Jones, 2004). First, to ensure instrument equivalence, the same cover letter and same items were used, and the items were forward and back translated. Special care was taken for the wording of the items to ensure they were culture-free. The data collection setting was similar in all countries, and the data were collected at the same time. Second, to ensure sample equivalence, potential differences in the respondents' countries of origin were assessed. Given the small sample size and its distribution into 25 countries, country differences were examined with a new variable coded $1=$ developing country $(n=38), 2=$ developed country $(n=83)$. This split was based on the World Bank (2014) classification. The compositional invariance was tested using a nonparametric measurement invariance of composite models (MICOM) procedure with 5,000 permutations (Henseler et al., 2016). All c values of the multiple indicator measures were not significantly different from $1(p>.05)$. Therefore, partial measurement invariance was established. Finally, after measurement invariance was established, the structural invariance of the model was examined (Henseler et al., 2016). Results of this analysis suggest no significant differences between the two groups. Thus, the conditions for analyzing the data as a whole were sufficient.

The likelihood of common method bias was minimized throughout the research process (Mohr and Spekman, 1994). At the data collection stage, the items in the questionnaire were mixed, and the respondents' identities were hidden. In the data analysis stage, we run the PLS model with a common method factor that included all observed variables of the model and linked it to all of the single indicator constructs converted from the observed indicators (Podsakoff et al., 2003; Liang et al., 2007). The results showed that most of the factor loadings of the method factor were not statistically significant and that the variances of each observed indicator explained by the substantive construct were substantially greater (on average .70) than their method variances (.02). Thus, common method bias is unlikely to be a serious concern in this study. 


\section{Results}

A total of 121 responses was received. The respondents were from different companies and represented 25 countries of origin (of the company). The respondents worked for companies in the pulp and paper (50\%), mineral concentrating (38\%) and metal-processing (12\%) industries. The two-step method was used to assess the measurement model and test the structural model (Anderson and Gerbing, 1988). The structural model was tested using PLS modeling with SmartPLS 3 software (Ringle et al., 2014). PLS was chosen for the analysis for three reasons. First, the goal was to predict key target constructs and identify the key drivers of the outcome constructs. Second, the model includes a formative-reflective second-order measure of channel effectiveness. Third, the sample size was small, and the data were non-normally distributed (see Hair et al., 2013, p. 19).

\subsection{Measurement model}

Construct reliability was assessed with Cronbach's alpha (threshold .70), average variance extracted (AVE, threshold .50) and composite reliability (threshold .8; Table II). All items loaded mainly on their intended constructs, and no statistically significant cross-loadings occurred on either the item or construct level. As the AVE values were above .50 and their square roots were larger than the correlation between the latent variable and all other latent constructs, the convergent and discriminant validity was adequate for further analyses (Anderson and Gerbing, 1988; Fornell and Larcker, 1981).

"Insert Table II about here"

\subsection{Structural model}

4.2.1 Direct effects 
In the model where communication channel effectiveness was considered a latent, second-order formative-reflective construct (see Hair et al., 2013, p. 231), all direct paths between the constructs were statistically significant. As shown in Figure 1, perceived value has a strong effect on channel effectiveness $(\beta=.60, p<.01)$ and communication quality $(\beta=.52, p<.01)$, as well as on loyalty $(\beta=.42, p<.01)$. The effect of channel effectiveness on loyalty $(\beta=.28, p<.01)$ was slightly stronger than the effect of communication quality $(\beta=.19, p<.01)$. Relationship age was controlled in order to tap potential differences between relationships, but there were no statistically significant differences between newer and more mature business relationships in terms of their effect on loyalty.

"Figure 1 about here"

\subsubsection{Mediation analysis}

The mediation hypotheses were tested following the suggestions of Hair et al. (2013, pp. 222-223), who first recommend evaluating whether the direct effect between the independent variable (perceived value) and the dependent variable (loyalty) is statistically significant in the absence of the mediators (true, $\beta=.68, p<.01$ ), between the independent variable and the mediators is statistically significant (true, see Figure 1) and between the mediators and the dependent variable is statistically significant (true, see Figure 1). Finally, in the presence of the mediators, the direct effect of perceived value on loyalty changed statistically significantly $(\Delta \beta=.68-.42=.27)$. As the effect decreased in the presence of the two mediators, a mediation effect was likely to occur.

Second, Hair et al. (2013, p. 223) suggest following Preacher and Hayes (2008) and bootstrapping the sampling distribution of the indirect effect. This approach suits PLS well and is suggested instead of using the common Sobel test. The results showed that when both mediators were considered simultaneously, the total indirect effect was statistically significant $(.27, p<.01$, 
Variance Accounted For $(\mathrm{VAF})=.24)$. The specific indirect effects $\left(\mathrm{IE}_{1}\right.$ : perceived value $\rightarrow$ channel effectiveness $\rightarrow$ loyalty: .17 , and $\mathrm{IE}_{2}:$ perceived value $\rightarrow$ communication quality $\rightarrow$ loyalty: .10) were also statistically significant at $p<.01$. The VAF value for the former $\left(\mathrm{IE}_{1}\right)$ was .58 , indicating that the effects of perceived value on loyalty are partially mediated by channel effectiveness. The VAF value for the latter relationship ( $\mathrm{IE}_{2}:$.19) indicated almost partial mediation. Thus, this result suggests hypothesis 1 was supported.

To test hypothesis 2 , the mediating effects of channel effectiveness were tested through its three first-order dimensions. How the specific three channels mediated the effects of perceived value on loyalty was then examined in more detail. The results (Table 3) indicate that in the presence of both mediators, including communication quality in all analyses (i.e., total indirect effect), all the total indirect effects were statistically significant at $p<.01\left(\mathrm{IE}_{\text {face-to-face }}: .20 ; \mathrm{IE}_{\text {mass media }}: .18\right.$; $\mathrm{IE}_{\text {personal via }}$ device: .21). Next, the specific indirect effects without the communication quality mediator were also assessed. The specific indirect effects were analyzed solely for the mediating effects of the channel effectiveness constructs. The indirect effect of perceived value on loyalty via mass media was not statistically significant (IE: .04, VAF .07). Regarding the mediating effect of face-to-face communication, the indirect effect $(.06, t=1.93)$ and mediation $(\mathrm{VAF}=.11)$ became marginally statistically insignificant. The indirect effect of perceived value on loyalty through the personal via device mediator (IE: .10, VAF: .18) remained statistically significant $(p<.01)$. These results, on one hand, indicate that of the specific sub-dimensions of channel effectiveness, personal channels (such as e-mail, telephone and face-to-face communication) are more important in transforming the effects of perceived value on loyalty; thus, H2 is supported. On the other hand, none of these proposed mediating effects was strong, as two of the indirect effects were not statistically significant (thus indicating no mediation) and all the VAF values remained below .20 (Hair et al., 2013, p. 225). Therefore, there was only partial support for H2. More likely, mediation occurs when 
channel effectiveness is considered a second-order factor and in the presence of communication quality.

\section{"Insert Table III about here"}

\section{Discussion}

\subsection{Theoretical contribution}

The aim of this study was to understand how customer-perceived value is transformed into loyalty via marketing communication. The results confirmed the previously well-documented direct link between perceived value and loyalty (Bell et al., 2005; Sirdeshmukh et al., 2002). Perceived value also influenced channel effectiveness and perceived communication quality, supporting the previous findings on the impact of customers' overall perception of the marketer when they receive marketing communications (Gilliland and Johnston, 1997; Palmatier et al., 2008). This result indicates that customer-perceived value is a critical determinant of experiences with a supplier and affects not only direct relationship outcomes but also the interactional element. Altogether, in line with previous literature, the importance of the value-based approach to managing business relationships is given more support by this study (Sharma et al., 2011).

Channel effectiveness and communication quality were found to be mediators of the effect of perceived value on loyalty. Specifically, channel effectiveness was a stronger mediator in this relationship. In order to find potential differences in the perceived effectiveness of different communication channels and their contribution to loyalty, the mediation effect of channel effectiveness was also tested channel-wise. The results suggest that the factor called "personal via device", had the largest mediating effect on the relationship between perceived value and loyalty, 
followed by the effect of face-to-face communication. The mediating effect of mass media was not statistically significant. Altogether, personal communication channels were observed to be stronger mediators of the effects of perceived value on loyalty. However, as the indirect effects were small, almost no mediation occurred.

Our results contribute to the knowledge on the effect of communication on business relationship outcomes (Ball et al., 2004; del Bosque Rodríguez et al., 2006) by suggesting that channel effectiveness and communication quality must be considered separately to manage business relationships successfully. When all communication channels were considered as a whole, communication channel effectiveness had greater importance as a mediator between perceived value and loyalty. In other words, the perceived effectiveness of communication in the form of different channels was more important for industrial customers than the perceived quality of communication. When communication channels were viewed separately in three groups, the quality of the communication had stronger effects on the transformation of value to loyalty than the effectiveness of certain channels. These results confirm the earlier findings of Mohr and Sohi (1995) that communication frequency is a driver of communication quality. In the present results, communication quality was related to increased loyalty to the supplier firm.

Foster (2006) concluded that Internet-based marketing tools were considered to have potential only in the "future" of industrial marketing communication. The findings about the perceived effectiveness of e-mail communication suggest that in recent years, industrial customers' preferences have clearly shifted to digital channels. However, our results confirm that in digital channels, personal and non-personal tools differ in terms of effectiveness just as they do in the more traditional channels. Digital tools also enable new forms of communication in which the traditional distinction between mass and face-to-face communication is not as clear-cut as it used to be. Digital 
channels such as company websites and e-mail may be used for both mass and personal communication.

Keller (2009) proposes that digital tools may not be very useful in influencing customer behavior in the post-purchase stage. The present study results partly confirmed and partly contradicted this observation in the B2B setting. On one hand, e-mail was among the channels that may be used to reinforce the transformation of customer value perceptions into customer loyalty. On the other hand, company website as a mass marketing tool was not perceived as effective. Company websites thus are merely a hygiene factor in communication, i.e. expected to exist but not benefiting an existing relationship. Our results resonate with recent findings from digital marketing research in that digital communication channels such as a company website or social media presence do not qualify as effective marketing communication alone (Cawsey and Rowley, 2016; Karjaluoto et al., 2015), but, when harnessed to support personalized communication such as the work of salespeople either in real-life or via communication devices, relationship outcomes are enhanced (Agnihotri et al., 2016; Trainor et al., 2014). In the same vein, the formerly superior effectiveness of face-to-face communication is now seen a slightly different light. In particular, trade shows have been a laborious but necessary part of the industrial marketing toolbox (Foster, 2006; McArthur and Griffin, 1997), whereas in this study, industrial customers did not consider trade shows to be very effective.

\subsection{Managerial implications}

A relevant question for managers is what elements are critical to the success of marketing communication that supports customer relationship objectives. The present findings provide marketing managers with several opportunities. Customer-perceived value affects communication quality such that as the value increases, communication is perceived more favorably. Therefore, 
industrial marketers should not be worried about causing "information overload" to their customers, as the present study showed that communication frequency contributes to the perceived communication quality. Those customers who find value in their supplier relationship also value frequent communication during the period between purchases and such transactions. The effectiveness of communication channels contributed to loyalty among customers - probably even more than communication quality. Effort should therefore be put in planning customer-specific channel mixes based on customer preferences.

Industrial companies may benefit from digital channels as a new way of conducting personal but effective marketing communications. The ease and low cost of making contact, the possibility of interacting personally and confidentiality without the requirement of physical proximity make technology-aided solutions a worthy communication channel. Video negotiations, (Internet) telephone calls and e-mail meet the customer's requirements for effectiveness in terms of the effortlessness. As for the quality of the communication, these device-mediated but personal channels enable more frequent exchange of customer-specific and up-to-date, thus, relevant information that contributes to the business relationship's well-being. Specifically, e-mail interaction is likely to be perceived as a personal communication channel if the relationship is already well established.

Companies have traditionally put a great deal of effort into participating in trade shows, and other events that require lots of resources. The results of this study show that existing customers do not consider such events effective regardless of their seemingly personal characteristics. This can be at least partly explained by other research showing that exhibitors set very vague goals at best for the events in which they participate (Pitta et al., 2006). Public events may be paralleled to other mass channels that do not create sufficiently personal and relevant communication between familiar 
business relationship parties. However, marketers should attempt to elicit positive word-of-mouth from their customers who interact with prospects and other industry actors in public events. This way, actively committed customers may build the brand among prospects more effectively than mass media advertising and such tools may yield, especially when cost efficiency is considered.

In existing relationships, marketing should support the work of the sales force by providing customer database information that may be used for additional purchases of services (Coviello and Brodie, 2001) so that the marketing resources are channeled effectively through the correct efforts to support sales objectives. This way, investments in relatively resource-consuming face-to-face interaction benefit the supplier as well.

\subsection{Limitations and suggestions for future research}

This study tested the causal links between customers' value perceptions, marketing communications and loyalty within B2B relationships. The sample consisted of industrial managers in various countries in industries where investments in manufacturing equipment are not often made, but when they are, the purchasing process is highly complex and critical to the customer and the supplier alike. Therefore, the results in this context may not be applicable in other industries or downward in the same supply channel. Additionally, within the limits of one study only some elements of a relationship can be studied. The present study focused on the role of value perceptions and marketing communications, and other central concepts of relationship theory, such as trust and satisfaction, were excluded.

Further research topics and questions for industrial marketing scholars emerge from this study. First, the mediating role of marketing communication in the value-loyalty linkage needs additional examination. The perceived differences in channel effectiveness imply that more channel-specific 
knowledge on industrial customers' preferences is needed to optimally allocate marketing resources. Gathering research data from the supplier side and the customer side simultaneously might shed light on the marketing communication process in terms of matching objectives and expectations in an evolving business relationship. 


\section{References}

Adamson, B., Dixon, M. and Toman, N. (2012), “The end of solution sales”, Harvard Business Review, Vol. 90 No. 7/8, pp. 61-68.

Agnihotri, R., Kothandaraman, P., Kashyap, R. and Singh, R. (2012), "Bringing 'social' into sales: the impact of salespeople's social media use on service behaviors and value creation", Journal of Personal Selling \& Sales Management, Vol. 32 No. 3, pp.333-348.

Andersen, P.H. (2001), "Relationship development and marketing communication: an integrative model", Journal of Business \& Industrial Marketing, Vol. 16 No. 3, pp. 167-183.

Anderson, J.C. and Gerbing, D.W. (1988), "Structural equation modeling in practice: A review and recommended two-step approach”, Psvchological Bulletin, Vol. 103 No. 3, pp. 411-423.

Anderson, E., Lodish, L.M. and Weitz, B.A. (1987), "Resource allocation behavior in conventional channels", Journal of Marketing Research, Vol. 24 (February), pp. 85-97.

Andreassen, T.W. and Lindestad, B. (1998), "Customer loyalty and complex services: The impact of corporate image on quality, customer satisfaction and loyalty for customers with varying degrees of service expertise", International Journal of service Industry management, Vol. 9 No. 1, pp.7-23.

Armstrong, J.S. and Overton, T.S. (1977), "Estimating nonresponse bias in mail surveys", Journal of Marketing Research, Vol. 14 No. 3, pp. 396-402. 
Ball, D., Simões Coelho, P. and Machás, A. (2004), "The role of communication and trust in explaining customer loyalty: An extension to the ECSI model”, European Journal of Marketing, Vol. 38 No. 9/10, pp. 1272-1293.

Bawden, D. and Robinson, L. (2009), "The dark side of information: overload, anxiety and other paradoxes and pathologies", Journal of Information Science, Vol. 35 No. 2, pp. 180-191.

Bell, S.J., Auh, S. and Smalley, K. (2005), “Customer relationship dynamics: service quality and customer loyalty in the context of varying levels of customer expertise and switching costs", Journal of the Academy of Marketing Science, Vol. 33 No. 2, pp. 169-183.

Bright, L.F., Kleiser, S.B. and Grau, S.L. (2015), "Too much Facebook? An exploratory examination of social media fatigue", Computers in Human Behavior, Vol. 44, pp. $148-155$.

Cannon, J.P. and Perreault, W.D., Jr. (1999), "Buyer-seller relationships in business markets", Journal of Marketing Research, Vol. 36 No. 4, pp. 439-460.

Cawsey, T. and Rowley, J., (2016), "Social media brand building strategies in B2B companies", Marketing Intelligence \& Planning, Vol. 34 No. 6, pp. 754-776.

Ciavolino, E. and Dahlgaard, J.J. (2007), "ECSI - Customer satisfaction modelling and analysis: a case study", Total Quality Management \& Business Excellence, Vol. 18 No. 5, pp. 545-554. 
Coviello, N.E. and Brodie, R.J. (2001), "Contemporary marketing practices of consumer and business-to-business firms: how different are they?", Journal of Business and Industrial Marketing, Vol. 16 No. 5, pp. 382-400.

Coviello, N.E. and Jones, M.V. (2004), "Methodological issues in international entrepreneurship research", Journal of Business Venturing, Vol. 19, pp. 485-508.

Coulter, K.S. and Coulter, R.A. (2002), "Determinants of trust in a service provider: the moderating role of length of relationship", Journal of Services Marketing, Vol. 16 No. 1, pp. 35-50.

del Bosque Rodríguez, I.R., Agudo, J.C. and Gutiérrez, H.S.M. (2006), "Determinants of economic and social satisfaction in manufacturer-distributor relationships", Industrial Marketing Management, Vol. 35 No. 6, pp. 666-675.

De Pelsmacker, P., Geuens M. and Van den Bergh, J. (2007), Marketing Communications. A European Perspective ( $3^{\text {rd }}$ ed.), Prentice-Hall, London, UK.

Duncan, T. and Moriarty, S. (1998), “A communication-based marketing model for managing relationships", Journal of Marketing Vol. 62 No. 2, pp. 1-13.

Dwyer, F.R., Schurr, P.H. and Oh, S. (1987), "Developing buyer-seller relationships", Journal of Marketing, Vol. 51 No. 2, pp. 11-27. 
Fang, E., Palmatier, R.W. and Evans, K.R. (2008), “Influence of customer participation on creating and sharing of new product value", Journal of the Academy of Marketing Science, Vol. 36 No. 3, pp. 322-336.

Fornell, C. and Larcker, D.F. (1981), "Evaluating structural equation models with unobservable variables and measurement error", Journal of Marketing Research, Vol. 18 No 1, pp. 39-50.

Foster, T. (2006), Industrial Marketing Communication: A (R) evolutionary Journey from Marketplace to Marketspace 1994-2005, Lulea University of Science and Technology, Department of Business Administration and Social Sciences, Sweden.

Gilliland, D.I. and Johnston, W.J. (1997), “Toward a model of business-to-business marketing communications effects", Industrial Marketing Management, Vol. 26 No. 1, pp. 15-29.

Hair, J.F., Jr., Hult, G.T.M., Ringle, C.M. and Sarstedt, M. (2013), A Primer on Partial Least Squares Structural Equation Modeling (PLS-SEM), Sage, Los Angeles.

Harcourt, J., Richerson, V. and Wattier, M.J. (1991), “A national study of middle managers' assessment of organization communication quality", Journal of Business Communication, Vol. 28 No. 4, pp. 348-365.

Harris, L.C and Goode, M.M.H. (2004), “The four levels of loyalty and the pivotal role of trust: a study of online service dynamics”, Journal of Retailing, Vol. 80 No. 2, pp. 139-158. 
Hennig-Thurau, T., Malthouse, E.C., Friege, C., Gensler, S., Lobschat, L., Rangaswamy, A. and Skiera, B. (2010), “The impact of new media on customer relationships”, Journal of Service Research, Vol. 13 No. 3, pp. 311-330.

Hutchinson, D., Wellington, W.J., Saad, M. and Cox, P. (2011), "Refining value-based differentiation in business relationships: a study of the higher order relationship buildingblocks that influence behavioral intentions", Industrial Marketing Management, Vol. 40 No. 3, pp. $465-478$.

Jussila, J.J., Kärkkäinen, H. and Aramo-Immonen, H. (2014), "Social media utilization in businessto-business relationships of technology industry firms", Computers in Human Behavior, Vol. 30, pp. 606-613.

Järvinen, J., Töllinen, A., Karjaluoto, H. and Jayawardhena, C. (2012), ’Digital and social media marketing usage in B2B industrial section", Marketing Management Journal, Vol. 22 No. 2, pp. 102-117.

Karjaluoto, H., Mustonen, N. and Ulkuniemi, P. (2015), "The role of digital channels in industrial marketing communications", Journal of Business \& Industrial Marketing, Vol. 30 No. 6, pp. 703-710.

Keller, K.L. (2009), "Building strong brands in a modern marketing communications environment", Journal of Marketing Communications, Vol. 15 No. 2/3, pp. 139-155. 
Kuhn, K.A.L., Alpert, F. and Pope, N.K.L. (2008), “An application of Keller's brand equity model in a B2B context", Qualitative Market Research: An International Journal, Vol. 11 No. 1, pp. $40-58$.

Kwak, H., Jaju, A. and Larsen, T. (2006), "Consumer ethnocentrism offline and online: the mediating role of marketing efforts and personality traits in the United States, South Korea, and India”, Journal of the Academy of Marketing Science, Vol. 34 No.3, pp. 367-385.

Lam, S.Y., Shankar, V., Erramilli, M.K. and Murthy, B. (2004), "Customer value, satisfaction, loyalty, and switching costs: An illustration from a business-to-business service context", Journal of the Academy of Marketing Science, Vol. 32 No. 3, pp. 293-311.

Liang, H., Saraf, N., Hu, Q. and Xue, Y. (2007), “Assimilation of enterprise systems: The effect of institutional pressures and the mediating role of top management", MIS Quarterly, Vol. 31 No. 1, pp. 59-87.

Taiminen, H. and Karjaluoto, H. (2015), "The usage of digital marketing channels in SMEs", Journal of Small Business and Enterprise Development, Vol. 22 No. 4, pp. 633-651.

McArthur, D.N. and Griffin, T. (1997), “A marketing management view of integrated marketing”, Journal of Advertising Research, Vol. 37 No. 5, pp. 19-26. 
Mohr, J.J., Fisher. R.J. and Nevin, J.R. (1996), "Collaborative communication in interfirm relationships: moderating effects of integration and control”, Journal of Marketing, Vol. 60 No. 3, pp. 103-115.

Mohr, J.J. and Sohi, R.S. (1995), "Communication flows in distribution channels: Impact on assessments of communication quality and satisfaction", Journal of Retailing, Vol. 71 No. 4, pp. 393-415.

Mohr, J. and Spekman, R. (1994), "Characteristics of partnership success: partnership attributes, communication behavior, and conflict resolution techniques", Strategic Management Journal, Vol. 15 No. 2, pp. 135-152.

Morgan, R.M. and Hunt, S.D. (1994), "The commitment-trust theory of relationship marketing", Journal of Marketing, Vol. 58 No. 3, pp. 20-38.

Palmatier, R.W., Scheer, L.K., Evans, K.R. and Arnold, T.J. (2008), “Achieving relationship marketing effectiveness in business-to-business exchanges", Journal of the Academy of Marketing Science, Vol. 36 No. 2, pp. 174-190.

Peltier, J., Schibrowsky, J.A., Schultz, D.E. and Zahay, D. (2006), “Interactive IMC: the relationaltransactional continuum and the synergistic use of customer data", Journal of Advertising Research, Vol. 46 No. 2, pp. 146-159.

Pitta, D.A., Weisgal, M. and Lynagh, P. (2006), "Integrating exhibit marketing into integrated marketing communications", Journal of Consumer Marketing, Vol. 23 No. 3, pp.156-166. 
Podsakoff, P.M., MacKenzie, S.B., Lee, J.-Y. and Podsakoff, N.P. (2003), “Common method biases in behavioral research: a critical review of the literature and recommended remedies", Journal of Applied Psychology, Vol. 88 No. 5, pp. 879-903.

Preacher, K.J. and Hayes, A.F. (2008), “Asymptotic and resampling strategies for assessing and comparing indirect effects in multiple mediator models", Behavior Research Methods, Vol. 40 No. 3, pp. 879-891.

Ringle, C.M., Wende, S. and Becker, J. (2014), Smartpls 3, Hamburg: SmartPLS. Retrieved from http://www.smartpls.com

Sasaki, Y., Kawai, D. and Kitamura, S. (2015), "The anatomy of tweet overload: How number of tweets received, number of friends, and egocentric network density affect perceived information overload", Telematics and Informatics, Vol. 32 No. 4, pp. 853-861.

Sashi, C.M. (2012), "Customer engagement, buyer-seller relationships, and social media", Management Decision, Vol. 50 No. 2, pp. $253-272$

Scheer, L.K., Miao, C.F. and Garrett, J. (2009), “The effects of supplier capabilities on industrial customers' loyalty: the role of dependence", Journal of the Academy of Marketing Science, Vol. 38 No. 1, pp. 90-104. 
Sharma, A., Krishnan, R. and Grewal, D. (2001), "Value creation in markets: A critical area of focus for business-to-business markets”, Industrial Marketing Management, Vol. 30 No. 4, pp. $391-402$

Sharma, A. and Mehrotra, A. (2007), "Choosing an optimal channel mix in multichannel environments“, Industrial Marketing Management, Vol. 36 No. 1, pp. 21-28.

Sirdeshmukh, D., Singh, J. and Sabol, B. (2002), "Consumer trust, value and loyalty in relational exchanges", Journal of Marketing, Vol. 66 No. 1, pp. 15-37.

Sweeney, J.C and Soutar, G.N. (2001), "Consumer perceived value: the development of a multiple item scale", Journal of Retailing, Vol. 77 No. 2, pp. 203-220.

Trainor, K.J., Andzulis, J.M., Rapp, A. and Agnihotri, R., (2014), "Social media technology usage and customer relationship performance: A capabilities-based examination of social CRM", Journal of Business Research, Vol. 67 No. 6, pp.1201-1208.

Ulaga, W. and Chacour, S. (2001), "Measuring customer-perceived value in business markets", Industrial Marketing Management, Vol. 30 No. 6, pp. 525-540.

Ulaga W. and Eggert, A. (2006), "Value-based differentiation in business relationships: gaining and sustaining key supplier status", Journal of Marketing, Vol. 70 No. 1, pp. 119-136. 
World Bank (2014), "Country and lending groups", available at: http://data.worldbank.org/about/country-and-lending-groups\#High_income [accessed 15 October 2015].

Zeithaml V. (1988), "Consumer perceptions of price, quality, and value: a means-end model and synthesis of evidence", Journal of Marketing, Vol. 52 No. 3, pp. 2-22. 


\section{List of Figures}

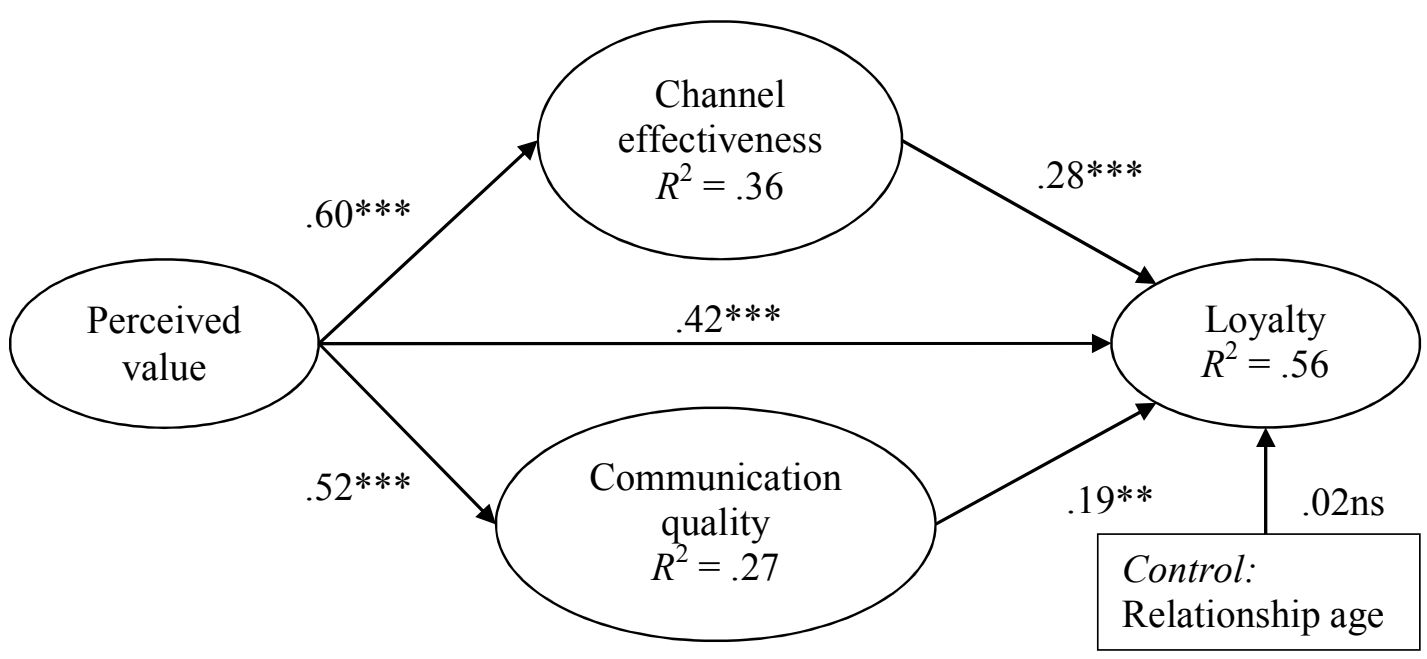

Figure 1. Structural model

Notes: $* * * p<0.01 ; * * p<0.05$ 


\section{List of Tables}

Table 1. Indicators and factor loadings

\begin{tabular}{lr}
\hline Measures $^{\mathrm{a}}$ & Loadings \\
\hline Perceived value (Compared to competitors... ) & \\
X is a reliable supplier & .81 \\
X is known to be environmentally conscious & .80 \\
X offers better products and solutions to improve our company's environmental performance than & .86 \\
its competitors do & .64 \\
X's price is reasonable in relation to the delivered outcome & .78 \\
X's products and solutions perform consistently & .83 \\
The products/services provided by X are of higher quality than those of others & \\
Channel effectiveness (2 ${ }^{\text {nd }}$ order) (Please rate the effectiveness of the following channels in \\
receiving information on X's products and solutions) & $.72^{\mathrm{b}}$ \\
Face-to-face & .79 \\
Face-to-face interaction with X & .81 \\
Interaction with others (e.g., colleagues) & .81 \\
Site visits & $.70^{\mathrm{b}}$ \\
Mass channels & .79 \\
Website & .77 \\
Trade shows & .71 \\
Seminars & .77 \\
Advertising & .75 \\
Magazine & $.81^{\mathrm{b}}$ \\
Personal via device & .87 \\
Telephone interaction with X & .87 \\
E-mail & \\
Communication quality & .81 \\
X contacts us with the adequate frequency & .88 \\
X provides useful information for our business & .89 \\
X uses suitable communications channels for us & .90 \\
X's communications are efficient & \\
X actively communicates solutions for improving the environmental performance of our \\
production & .76 \\
Loyalty (How likely are you to... & \\
Do most of your future business in this sector with X? & \\
Use X the next time you need similar products/services? & .93 \\
Recommend X to other firms? & .96 \\
\hline
\end{tabular}

${ }^{a}$ Perceived value and communication quality were measured on 7-point Likert scale $(1=$ strongly disagree; $7=$ strongly agree); Channel effectiveness was measured on a 7 -point scale ranging from $1=$ not at all effective to $7=$ extremely effective $\left(2^{\text {nd }}\right.$-order factor); Loyalty was measured on a 10 -point scale $(1=$ very unlikely; $10=$ very likely $)$.

${ }^{\mathrm{b}} 2^{\text {nd }}$-order factor loadings 
Table 2. Measurement model

\begin{tabular}{lcccccccc}
\hline & Alpha & CR & AVE & 1 & 2 & 3 & 4 & 5 \\
\hline 1. Perceived value & .88 & .91 & .62 &. $\mathbf{7 9}$ & & & & \\
2. Channel effectiveness & a & - & - & - & .60 & - & & \\
3. Communication quality & .90 & .93 & .72 & .52 & .57 & $\mathbf{. 8 5}$ & & \\
4. Loyalty & .93 & .96 & .88 & .68 & .63 & .56 & .94 & \\
5. Relationship age & - & - & - & -.17 & -.11 & -.06 & -.09 & - \\
\hline M & & & & 4.68 & 4.86 & 4.85 & 6.95 & 2.91 \\
SD & & & & 1.29 & 1.30 & 1.39 & 2.00 & 0.99 \\
\hline
\end{tabular}

Notes: The square root of the AVE is on the diagonal (in bold).

a - = not applicable: Cronbach's alpha, CR, AVE cannot be computed because channel effectiveness was measured as a formative-reflective second-order factor and relationship age as a single indicator.

Table 3. Mediation analysis

\begin{tabular}{|c|c|c|c|c|c|}
\hline & $\begin{array}{c}\text { Specific } \\
\text { indirect effects }\end{array}$ & $\begin{array}{c}\text { Total indirect } \\
\text { effects }\end{array}$ & $\begin{array}{l}\text { Total } \\
\text { effects }\end{array}$ & VAF & Mediation \\
\hline $\mathrm{PV} \rightarrow$ Channel effectiveness $^{\mathrm{a}} \rightarrow$ Loyalty & $.17 * *$ & & $.28 * *$ & .58 & Partial \\
\hline $\mathrm{PV} \rightarrow \mathrm{CQ} \rightarrow$ Loyalty & $.10 * *$ & & $.19 * *$ & .19 & No \\
\hline $\mathrm{PV} \rightarrow$ Loyalty & & $.27 * *$ & $.68 * *$ & .24 & Partial \\
\hline PV $\rightarrow$ Face-to-face $\rightarrow$ Loyalty & $.06 * *$ & & $.54 * *$ & .11 & No \\
\hline $\mathrm{PV} \rightarrow \mathrm{CQ} \rightarrow$ Loyalty & $.14 * *$ & & $.62 * *$ & .22 & Partial \\
\hline $\mathrm{PV} \rightarrow$ Loyalty & & $.20 * *$ & $.68 * *$ & .29 & Partial \\
\hline $\mathrm{PV} \rightarrow$ Mass media $\rightarrow$ Loyalty & $.04 \mathrm{~ns}$ & & $.54 * *$ & .07 & No \\
\hline $\mathrm{PV} \rightarrow \mathrm{CQ} \rightarrow$ Loyalty & $.14 * *$ & & $.64 * *$ & .22 & Partial \\
\hline $\mathrm{PV} \rightarrow$ Loyalty & & $.18 * *$ & $.68 * *$ & .26 & Partial \\
\hline $\mathrm{PV} \rightarrow$ Personal via device $\rightarrow$ Loyalty & $.10^{* *}$ & & $.57 * *$ & .18 & No \\
\hline $\mathrm{PV} \rightarrow \mathrm{CQ} \rightarrow$ Loyalty & $.11 * *$ & & $.58 * *$ & .19 & No \\
\hline $\mathrm{PV} \rightarrow$ Loyalty & & $.21 * *$ & $.68 * *$ & .31 & Partial \\
\hline
\end{tabular}

Notes:

$\mathrm{PV}=$ Perceived value

$\mathrm{CQ}=$ Communication quality

** $p<0.01 ; * p<0.05$.

${ }^{\text {a }}$ Construct modeled as $2^{\text {nd }}$ order factor

ns $=$ Not significant 